1* Д.е.н., професор каф. «Економіка промисловості та організація виробництва», ДВНЗ «Український державний хіміко-технологічний університет», проспект Гагаріна, 8, 49005, Дніпро, Україна, тел. (056) 24714-83 ел. пошта qarm@ukr.net

2* к.е.н., доцент каф. «Економіка промисловості та організація виробництва», ДВНЗ «Український державний хіміко-технологічний університет», проспект Гагаріна, 8, 49005, Дніпро, Україна, тел. (056) 24714-83, ел. пошта starfire111@rambler.ru

\title{
МОТИВАЦІЙНІ ПІДПРИЕМСТВА
} ФАКТОРИ РЕЗУЛЬТАТИВНОСТІ ПЕРСОНАЛУ

Мета. Робота присвячена дослідженню впливу мотивації працівників на результативність їх діяльності. Методика. Для обгрунтування заходів щодо підвищення рівня результативності працівників використано методи індивідуальної (персональної) експертної оцінки: інтерв'ю та анкетування; запропоновано до використання матричний метод аналізу результативності (Performance Analysis Quadrant, PAQ). Результати. У роботі наведено методичний підхід, який базується на використанні матричних методів стратегічного аналізу, що дозволяє забезпечити швидку адаптацію до зовнішніх умов, зменшити невизначеність і ризик у господарській діяльності та забезпечити концентрацію трудових ресурсів на обраних пріоритетних напрямах. Практична значимість полягає у демонструванні використання матричних методів для аналізу результативності персоналу підприємств, коли використання лише одного класичного діагностичного методу неможливо через велику кількість факторів, що безпосередньо впливають на результативність працівників та розробка заходів щодо підвищенню рівня результативності працівників досліджуваних торговельних підприємств, яка залежить від впливу мотиваційних факторів.

Ключевые слова: персонал; оценка; мотивация; факторы; торговое предприятие.

\section{Вступ}

У діяльності підприємства мотивація грає величезну роль, так воно спрямоване на мотивацію працівника до ефективної і якісної праці, яка не лише покриває витрати працедавця на організацію процесу виробництва, оплату праці, але і дозволяє отримати певний прибуток. Одним 3 найскладніших завдань в діяльності підприємства $€$ управління трудовими ресурсами. Працівник досягає значних результатів в праці, коли він захоплений суспільно значимою метою, коли у нього є відповідна мотивація, коли він досягає задоволеності процесом діяльності. Практичне застосування теоретичних основ дослідження мотивації, законів, закономірностей i сформульованих на цій основі принципів i правил мотивації в діяльності підприсмства дозволяють підвищити ступінь обгрунтованості рішень, що приймаються, повніше використати наявні ресурси через мотивацію трудової діяльності. У зв'язку 3 цим залишається актуальним дослідження мотиваційних факторів, що впливають на результативність праці робітників торговельних підприємств.

\section{Аналіз останніх досліджень і публікацій}

Аналіз концептуальних підходів до проблеми мотивації трудової діяльності спирається на теоретико-методологічні уявлення про різні аспекти мотивації, сформульовані в працях вітчизняних i зарубіжних дослідників, таких, як: Богиня Д.П. [1], Колот А. М. [4], Маслоу А. [6], Садєков А. А. та Д.М. Прусс [7], Шапиро С.А. [8], та ін. Але навіть в цих роботах методологія збору інформації i аналізу не дозволяє узагальнити отримані результати i одержати повніші (що виходять за рамки окремо взятої ситуації i конкретного підприємства) висновки щодо причини i закономірності впливу структури мотивації працівників сучасних українських підприємств на результативність їх праці. Ця обставина у поєднанні 3 актуальністю поставленої проблематики зумовили формулювання мети і завдань дослідження. 


\section{Формулювання цілей статті (постановка завдання)}

Вивчення впливу мотивації працівників на результативність їх діяльності.

\section{Виклад основного матеріалу дослідження}

$\begin{array}{cll}\text { Дослідження } & \text { мотивації } & \text { персоналу } \\ \text { проводилося на } & \text { практичних } & \text { матеріалах }\end{array}$

підприємств роздрібної торгівлі м. Дніпропетровська та Дніпропетровської області. Ці підприємства було згруповано залежно від розміру торговельної площі та чисельності персоналу (табл. 1)

Досліджувані торговельні підприємства за групами

\begin{tabular}{|c|c|c|c|}
\hline $\begin{array}{c}\text { Групи } \\
\text { підприємств }\end{array}$ & $\begin{array}{c}\text { Найменування досліджуваних } \\
\text { підприємств }\end{array}$ & $\begin{array}{l}\text { Середній розмір } \\
\text { торговельної } \\
\text { площі, м² }\end{array}$ & $\begin{array}{c}\text { Середня } \\
\text { чисельність } \\
\text { персоналу, чол. }\end{array}$ \\
\hline 1 (малі) & $\begin{array}{l}\text { ПП «Антоніо Біаджі»; ПП } \\
\text { «Лагуна»; ПП «Ігла»; ТОВ } \\
\text { «Акватика»; ТОВ «Акваторія»; } \\
\text { ТОВ «Карло Пазоліні Трейдінг»; } \\
\text { ТОВ «Кіра Пластініна»; ТОВ "Дім } \\
\text { Тканини» }\end{array}$ & 400 & 47 \\
\hline 2 (середні) & $\begin{array}{l}\text { TOB «Омега» (супермаркет } \\
\text { VARUS); TOB "АТБ-маркет"; } \\
\text { TOB «Комфі Трейд»; ТОВ «Ібоя } \\
\text { Преміум»(супермаркет } \\
\text { Будапешт); TM «АБВ-техніка»; } \\
\text { TM «Фокстрот» }\end{array}$ & 6000 & 110 \\
\hline 3 (великі) & $\begin{array}{l}\text { TOВ "Торговельний комплекс } \\
\text { "МЕТЕОР"; ТМ «МЕТРО»; АТ } \\
\text { «Нова Лінія»; ТМ «Епіцентр К» }\end{array}$ & 16000 & 500 \\
\hline
\end{tabular}

Оцінку мотивації персоналу підприємства у рамках групи було проведено методами індивідуальної (персональної) експертної оцінки: інтерв'ю та анкетування. Для того щоб проаналізувати, наскільки процес мотивації робітників досліджуваних підприємств допомагає привести якість їх роботи у відповідність до корпоративних стандартів, адаптувати їх діяльність до вимог, що змінилися, при впровадженні нових технологій, освоєнні нового устаткування, застосуємо матрицю аналізу результативності (Performance Analysis Quadrant, PAQ). Результати оцінки результативності наведено на рис. 1.

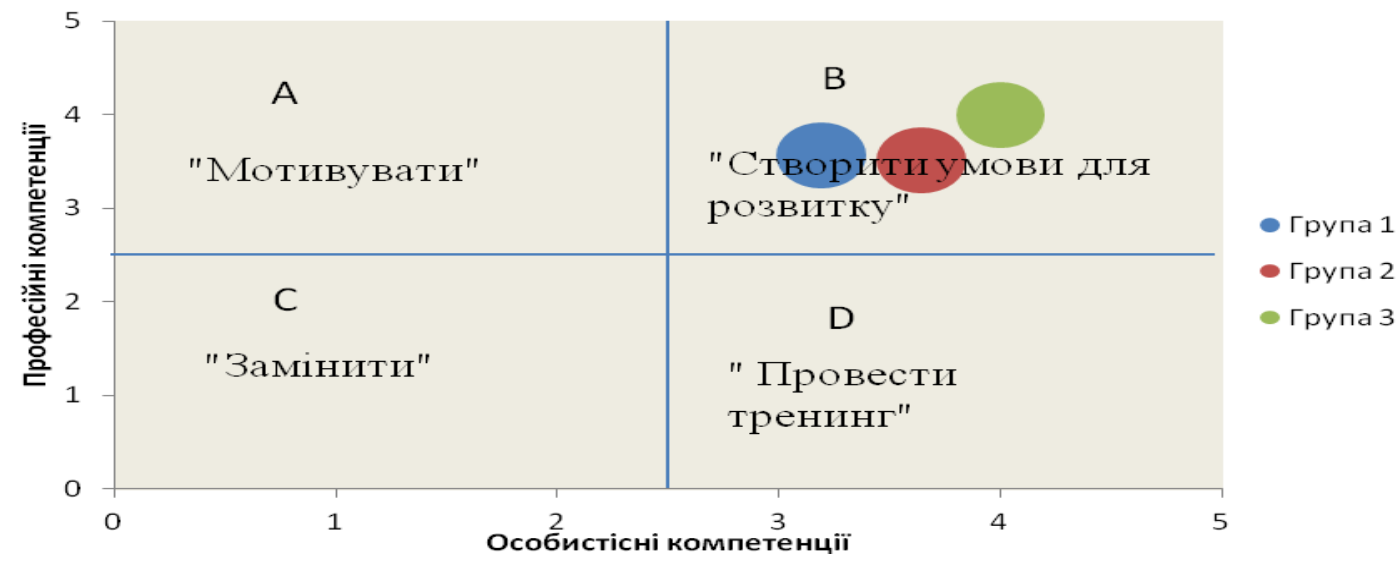

Рис. 1. Матриця аналізу результативності персоналу досліджуваних торговельних підприємств 
Згідно 3 матрицею аналізу результативності працівники досліджуваних підприємств потрапляють в Квадрант В (ресурси/процеси/середовище). Тобто працівники мають достатній рівень знань, умінь, навичок. Низькі показники результативності пов'язані з проблемами, які вони не можуть контролювати, швидше за все - 3 нестачею часу i т. д. Підвищити їх результативність шляхом аналізу якості лінійного менеджменту і усунення недоліків в плануванні і організації діяльності.

Для більш детальнішого розуміння причин низької результативності працівників торговельних підприємств, що досліджувалися, нами було проведено опитування 550 працівників підприємств, що досліджувалися у розрізі категорій (адміністративно-управлінський, торговооперативний, допоміжний) наступних блоків: мотиваційні фактори, задоволеність персоналу роботою. Оцінку визначених потреб проводилося опитуванням за п’ятибальною шкалою за такими показниками: важливість потреби для даної категорії персоналу, вірогідність задоволення цієї потреби.

В результаті дослідження було складено мотиваційну карту персоналу підприємств, що досліджувалися у розрізі категорій, яка демонструє домінуючі для працівників елементи мотивації (табл. 2 ).

Таблиця 2

Мотиваційна карта персоналу підприсмств, що досліджувалися, у розрізі категорій

\begin{tabular}{|l|l|l|}
\hline \multicolumn{1}{|c|}{ Категорія персоналу } & \multicolumn{1}{|c|}{ Потреби } & Мотиви \\
\hline $\begin{array}{l}\text { Адміністративно-управлінський } \\
\text { персонал }\end{array}$ & $\begin{array}{l}\text { Інтелектуальні } \\
\text { Соціальні } \\
\text { Емоційні } \\
\text { Самовираження }\end{array}$ & \\
\hline Торгово-оперативний персонал & Фізіологічні & \\
& Матеріальні & $\begin{array}{l}\text { Моральне заохоченння } \\
\text { Самозатвердження }\end{array}$ \\
& Емоційні & \\
& Духовні & \\
& Самовираженні & Матеріальне заохочення \\
Допоміжний персонал & Фізіологічні & Моральне заохочення \\
& Матеріальні & \\
& Соціальні & \\
& Емоційні & \\
\hline
\end{tabular}

Побудована мотиваційна карта демонструє, що в межах категорій персоналу на працівників практично однаково діють фактори мікросередовища, не залежно від підприємства, в якому він працює. В цьому проявляється закон підвищення потреб. Люди, які досягли вже певних результатів в житті та мають необхідний рівень достатку, прагнуть підвищити свій соціальний статус та соціальну роль в суспільстві. Пріоритетами для них виступають самоповага, самовизначення, комфортне життя, успіх, свобода. Люди, які ще не досягли цього, апелюють у своїй діяльності функціональними і економічними цінностями.

Результати оцінки показують, що серед адміністративно-управлінського персоналу всіх підприємств найбільшу важливість грають потреби в належних умовах праці, потреба у приналежності до колективу, потреба в визнанні і підтримці, потреба у впливі на людей та владі, потреба у навчанні і розвитку (за всіма групами підприємств 5 балів); менш важливими $є$ потреба у чіткому структуруванні робіт та потреба бути креативним. Потреба в соціальних контактах велику важливість грає тільки для менеджерів групи 3. Серед торговооперативного персоналу найбільшу важливість мають: потреба у чіткому структуруванні робіт, потреба у приналежності до колективу, потреба у змінах та різноманітності, потреба в самовдосконаленні, потреба у навчанні i розвитку (за всіма групами підприємств 5 балів). Найменша важливість віддається потреби бути креативним (4 бали - у підприємствах групи $1,3,4 ; 3$ бали - y підприємствах групи 2). Допоміжний персонал більшу значимість віддає потребі належних умовах праці (4 бали - в підприємствах групи 1; 3 бали - в підприємствах групи 2,3,4) та потребі у навчанні та розвитку (4 бали за всіма групами підприємств). Також слід відмітити, що потреба у високій заробітній платі грає велику значущість для всіх працівників (5 балів за всіма групами підприємств). 
Review of transport economics and management, 2019, вип.1(17)

За ступенем вірогідності задоволення існуючих потреб найбільш вірогідним для адміністративно-управлінського персоналу $\epsilon$ задоволення потреби у впливі на людей та владі, для торгово-оперативного персоналу потреби ставити для себе складні цілі та досягати їх, самовдосконаленні (5 балів за всіма групами підприємств). Всі працівники відмітили високу вірогідність задоволення потреб у високій заробітній платі.

Наступним етапом дослідження виступило виявлення ступеню задоволеності роботою персоналу підприємств, що досліджувалися та факторів, що негативно впливають на результативність праці й визивають незадоволеність цією працею:

1. Ступінь задоволеністю працею всіх категорій персоналу для всіх груп підприємств, що досліджувалися складає від 70\% (для адміністративно-управлінського персоналу) до 80-90 \% (торгово-оперативного персоналу та допоміжного персоналу). Рівень своєї трудової активності всі категорії персоналу оцінили на 80-90\%.

2. Серед умов праці для адміністративно-управлінського персоналу підприємств, що досліджувалися повністю влаштовують самостійність у роботі та можливість підвищення кваліфікації, участь в управлінні; повністю не влаштовують відносини 3 колегами. Торгово-оперативний персонал підприємств, що досліджувалися частково влаштовують розмір заробітку, система заохочення та не влаштовують можливість професійного зростання, підвищення кваліфікації, участь в управлінні. Допоміжний персонал підприємств, що досліджувалися не влаштовують режим, графік робочого дня, інтенсивність праці, розмір заробітку, можливості підвищення кваліфікації, система заохочення, виробничий побут та почасти влаштовує - технічна оснащеність, стан устаткування.

3. Рівень результативності i ефективності своєї роботи адміністративноуправлінський та допоміжний персонал підприємств, що досліджувалися характеризують як повністю відповідний необхідному рівню виконання (досягаються всі необхідні цілі і завдання); торгово-оперативний - на «добре», але деякі аспекти вимагають поліпшення для досягнення стандартів відмінного виконання.
4. Ступінь задоволеністю формами стимулювання різні категорії персоналу оцінили по різному. Адміністративноуправлінський персонал підприємств, що досліджувалися не зовсім задоволені обсягом матеріального стимулювання; об'єктивністю оцінки ступеню вкладу та результатів праці; знання й професійні навички використовуються на 40\% - на $60 \%$. Основними перешкодами повному використанню потенціалу опитувані вважають - відсутність повної і своєчасної інформації, тому невикористані резерви присутні у сфері організації праці, у невикористанні ініціативи i творчого потенціалу.

Торгово-оперативний персонал підприємств, що досліджувалися не задовольняють об'єктивність оцінки вкладу, що вноситься своїми ідеями та пропозиціями, об'єктивність системи матеріального стимулювання, системи преміювання i штрафів. Основні перешкоди повному використанню потенціалу вони вважають відсутність чіткої постановки завдань 3 боку керівництва, суб'єктивне відношення між начальником і підлеглими, відсутність повної і своєчасної інформації, відсутність достатнього зворотного зв'язку, відсутність підтримки ініціативи i довіри 3 боку керівництва. Невикористані резерви на думку торгово-оперативного персоналу присутні у відсутності умов для навчання та розвитку, у невикористанні ініціативи i творчого потенціалу.

Допоміжний персонал підприємств, що досліджувалися не задовольняють матеріальні форми стимулювання (зокрема, система преміювання і штрафів), їх знання й професійні навички використовуються на 60 \%. Основною перешкодою вони вважають відсутність достатнього зворотного зв'язку від керівника відносно роботи, недостатньо високий рівень виконавчої дисципліни. Невикористаними резервами, на думку допоміжного персоналу підприємств $є$ не використання ініціативи i творчого потенціалу співробітників, відсутність стимулювання у співробітників творчої ініціативи.

\section{Висновки}

Отже, підсумовуючи сказане вище, зазначимо, що підвищенню рівню результативності працівників досліджуваних торговельних підприємств сприятиме впровадження таких заходів: 
Review of transport economics and management, 2019, вип.1(17)

- позитивний рух кадрів. Для підвищення кадрового потенціалу необхідно створювати належні умови для роботи персоналу, щоб не відбувалося відтоку найкращих кадрів у інші галузі або на інші підприємства, а також залучення нових висококваліфікованих кадрів та формування резерву з обдарованої молоді; підвищення кваліфікаційного рівня працівників через участь у різноманітних курсах підвищення кваліфікації і тематичних навчаннях, застосування обміну досвідом;

- $\quad$ надання консультаційних послуг щодо діяльності підприємства;

- підвищення освітнього рівня працівників, сприяння навчанню працівників; формування позитивної атмосфери у колективі, скорочення кількості конфліктних ситуацій;

- розкриття здібностей працівників, стимулювання працівників для розробки нових бізнес-ідей та раціоналізаторських пропозицій;

- п проведення ефективної мотиваційної політики з врахування побажань працівників 3 метою підвищення продуктивності праці та активності працівників;

- сприяння збереженню i покращанню здоров'я персоналу та створення відповідних умов для праці, що зможе ліквідувати або ж значно зменшити негативний вплив роботи на здоров'я працівників, особливо у шкідливих умовах праці.

\section{БІБЛІОГРАФІЧНИЙ СПИСОК}

1. Богиня Д. П. Основи економіки праці / Д. П. Богиня, О. А. Грішнова. - К. : Знання-Прес, 2006. $-313 \mathrm{c}$.

2. Гурова К. Д. Формування системи мотивації персоналу під- приємства в умовах глобалізації / К. Д. Гурова // Бізнес- інформ. - 2010. - № 4. - С. 102-104.

3. Дуда С. Т. Мотивація та результативність праці персоналу підприємства : їх сутність та взаємозв’язок / С. Т. Дуда // Науковий вісник НЛТУ України. - 2010. - № 20.14. - С. 188-193.

4. Колот А. М. Мотивація персоналу / А. М. Колот. - К. : КНЕУ, 2002. - 337 с.

5. Маринич I. А. Мотивація як фактор підвищення ефективності праці працівників / I. А. Маринич // Науковий вісник НЛТУ України. - 2011. - № 15.5. - С. 376-380.

6. Маслоу А. Мотивація і особистість / А. Маслоу - СПб.: Видавництво Пітер, 2006 р. - 352 с.

7. Садєков А. А. Мотивація персоналу торговельних підприємств: монографія / А.А. Садєков, Д.М. Прусс. - Донецьк : ДонНУЕТ, 2010. - 251 с.

8. Шапиро С.А. Основы трудовой мотивации / С.А. Шапиро. - М.: КНОРУС, 2011. — 256 с.

\section{ГАРМИДЕР Л. Д. ${ }^{1^{*}}$, ГОНЧАР Л.А ${ }^{2 *}$}

$1^{*}$ Д.э.н., профессор каф. «Экономика промышленности и организация производства», ГВУз «Украинский государственный химико-технологический университет», проспект Гагарина, 8, 49005, Днепр, Украина, тел. (056) 247-14-83 эл. почта qarm@ukr.net

2* к.э.н., доцент каф. «Экономика промышленности и организация производства», ГВУЗ «Украинский государственный химико-технологический университет», проспект Гагарина, 8, 49005, Днепр, Украина, тел. (056) 247-14-83 эл. почта starfire111@rambler.ru

\section{МОТИВАЦИОННЫЕ ФАКТОРЫ РЕЗУЛЬТАТИВНОСТИ ПЕРСОНАЛА ПРЕДПРИЯТИЯ}

Цель. Работа посвящена исследованию влияния мотивации работников на результативность их деятельности. Методика. Для обоснования мероприятий по повышению уровня результативности работников использованы методы индивидуальной (персональной) экспертной оценки: интервью и анкетирование; предложен к использованию матричный метод анализа результативности (Performance Analysis Quadrant, PAQ). Результаты. В работе приведен методический подход, который базируется на использовании матричных методов стратегического анализа, что позволяет обеспечить быструю адаптацию персонала к внешним условиям, уменьшить неопределенность и риск в хозяйственной деятельности и обеспечить концентрацию ресурсов на избранных приоритетных направлениях. Практическая значимость заключается в демонстрировании использования матричных методов для анализа результативности 
Review of transport economics and management, 2019, вип.1(17)

персонала предприятий, когда использование лишь одного классического диагностического метода невозможно из-за большого количества факторов, которые непосредственно влияют на результативность.

Ключевые слова: персонал оценка; мотивация; факторы; торговое предприятие.

HARMIDER L.D. ${ }^{1^{*}}$, GONCHAR L.A. ${ }^{2^{*}}$

${ }^{1 *}$ Ph.D. in Economics, Professor of the Department " Economics of industry and organization of production ", DHEI "Ukrainian state chemical and technological university", 8, Gagarina street, 49005, Dnipro, Ukraine, tel. (056) 247-14-83, e-mail: qarm@ukr.net

${ }^{2 *}$ Ph.D. in Economics, Associate Professor " Economics of industry and organization of production ", DHEI "Ukrainian state chemical and technological university", 8, Gagarina street, 49005, Dnipro, Ukraine, tel. (056) 247-14-83, e-mail:

starfire111@rambler.ru

\section{MOTIVATION FACTORS OF PERFORMANCE OF PERSONNEL OF THE ENTERPRISE}

Purpose. The work is devoted to the study of the impact of employees' motivation on the performance of their activities. Method. Methods of individual (personal) expert evaluation of interviewing and questioning were used to justify measures to increase the level of employees' performance; Performance Analysis Quadrant (PAQ) has been proposed for use. Results. The methodical approach is based on the use of matrix methods of strategic analysis of employees' performance, which allows to ensure rapid adaptation to external conditions, reduce uncertainty and risk in economic activity and ensure concentration of resources in selected priority directions. Practical significance is the demonstration of the use of matrix methods for the analysis of the effectiveness of personnel of enterprises when the use of only one classical diagnostic method is impossible due to the large number of factors that directly affect the effectiveness of employees and the development of measures to increase the effectiveness of employees of investigated trading enterprises, which depends on the influence of motivational factors.

Key words: personnel; evaluation; motivation; factors; trading enterprise.

\section{REFERENCES}

1. Bogynja, D.P., \& Grishnova, O.A. (2006). Osnovy ekonomiky praci [Product innovative policy]. Kiyv: «Znannya-Press» [in Ukrainian].

2. Gurova, K.D. (2010). Formuvannja systjemi motyvacii pjersonalu pidpryemstva v umovah globalizacii [Formation of a company motivation system in the conditions of globalization ]. BiznesInform, 4, 102-104 [in Ukrainian].

3. Duda, S.T. (2010). Motyvacija ta rezul'tatyvnist' praci personalu pidpryemstva: jih sutnist' ta vzaemozv'jazok [Motivation and productivity of the personnel of the enterprise: their essence and interconnection]. Nvukovyj visnyk NLTU Ukrainy, 20.14, 188-193 [in Ukrainian].

4. Kolot, A.M. (2002). Motyvacija personalu [Marketing distribution policy]. Kyiv: KNEU [in Ukrainian].

5. Marynich, I.A.(2011). Motyvacija jak faktor pidvyshennja jefjektyvnosti praci pracyvnykiv [Motivation as a factor in improving employee productivity]. Nvukovyj visnyk NLTU Ukrainy, 15.5, 376380 [in Ukrainian].

6. Maslou, A. (2006). Motyvacija i osobystist' [Marketing distribution policy]. Sankt-Peterburg: Piter [in Ukrainian].

7. $\quad$ Sadekov, A.A., \& Pruss, D.M. (2010). Motyvacija personalu torgovel'nyh pidpryemstv [Product innovative policy]. Donetsk: Don NUET [in Ukrainian]

8. Shapiro, S.A. (2011). Osnovy trudovoj motivacii [Marketing distribution policy]. Moskva: KNORUS [in Russian].

Надійшла 10.04.2019 p.

Стаття рекомендована до друку д-ром екон. наук, доц. Жилінською Л.О., д-ром екон. наук, доц. Бобилем В.В. 